\title{
Gulu-kula: dogs in Anbarra Society, Arnhem Land
}

\author{
Betty Meehan, Rhys Jones and Annie Vincent
}

Canines in Australian Aboriginal society have turned out to be a considerable puzzle to anthropology. The role and significance of dogs, and traditionally dingoes, in this society had previously been so taken for granted as to be beyond reasonable doubt. In recent years, however, a lively, though sometimes 'dogged', debate has developed that demonstrates otherwise. The debate is fired by more or less radical departures from the economic-utilitarian perspective that attributes to canines a decisive usefulness in man's food quest. Indeed this is usually seen as the primary reason for the animal's domestication (Kolig 1978: 84).

In 1972, Isobel White published an article about the role of dogs in Aboriginal society. In so doing, she was contributing to a lively debate which had been initiated by Mervyn Meggitt in 1965 and which continued intermittently over the next two decades, primarily in the pages of the now sadly defunct journal Mankind (Gould 1967, 1968; Jones 1970, White 1972, Hamilton 1972, Kolig 1973, Long 1974, Hayden 1975, and Kolig 1978). Meggitt had examined the hypothesis proposed by archaeo-zoologists that the original domestication of the dog had occurred from the wolf by Mesolithic hunting peoples within the geographical context of northern Eurasia during early post-glacial times, perhaps some 10000 years ago (Downs 1960). This was believed to have been the first successful domestication experiment carried out by humans and to have occurred due to a symbiosis of mutual ecological advantage between the two species. Both man and dog are social animals, and dogs are capable of being incorporated into the social hierarchies and bonding relationships of a human world. In return, the dogs' acute senses of smell and of hearing and their speed gave human hunters a major advantage in their foraging strategies. There is direct archaeological evidence for wolf-like dogs associated with Mesolithic hunting and gathering sites in northern Britain, such as at the famous swamp-edge site of Star Carr in Yorkshire, dated to about 9000 years BP (Clark 1953, Degerbol 1961). Other canids, believed to be domesticates have been found in the Middle East, within archaeological contexts which span the boundary between terminal hunting and the earliest farming societies at about 12000 years ago, such as the epi-Palaeolithic Zarzian site of Palegawra Cave in Iraqi Kurdistan (Turnbull and Reed 1974) and Natufian sites in Israel (Davis and Valla 1978). In northeastern Asia too, there are dogs of the same order of age in cave sites in Japan (Lawrence 1967, Ikawa 1964), and importantly also in north America, such as at Ventana Cave in Arizona, dated to some 11000 years ago (Colton 1970: 153), and in pre-Inca Peru (Wing 1977), 
suggesting strongly that some of the first immigrant groups into the American continent were also accompanied by an early domesticated dog.

Recent genetic research has not only confirmed some of these ideas, but has indeed extended aspects further back in time. According to Vila et al. (1997), mitochondrial DNA studies on samples, firstly from more than 150 wolves around the world and secondly from 140 domestic dogs representing about 65 breeds, have shown that all of the dog breeds had only one original forebear, namely the wolf. The latter included wolf populations from both Eurasia and North America, and the dating of wolf-dog separation must be substantial. Since the time of Pliny the Elder's description in his book Naturalis Historia of Gauls tying their female dogs in the woods to mate with wolves and thus increase the strength of the progeny, it has been known that wolves and dogs can readily interbreed. This Classical observation has been confirmed by recent genetic research (Wayne and Ostrander 1999), and there appear to have been at least four separate domestication or back-breeding events leading to different geographic populations of domestic dogs. As to the timing of these events, according to personal information from Murray Cox, from the University of Otago, 'a date of 12000 years BP, as an archaeologically supported proposition, is not inconsistent with the genetic data'.

In general, the arguments put by Downs (1960) and other archaeologists have been at a utilitarian, ecological level posited in terms of selective advantage: that the use of dogs gave those communities which possessed them greatly superior success rates in hunting efficiency. Conversely, for the dogs involved, association with humans afforded protection and access to a range of new nutritional resources unavailable to them in the wild state. For this debate, the Australian data hold a central place (Manwell and Baker 1984). Here was an entire continent inhabited by hunters and gatherers until the advent of the Europeans in recent times. Widespread throughout its various ecological zones, though significantly not on the island of Tasmania, was the dingo, a subspecies of wild $\mathrm{dog}$, which had been on the continent for several thousand years. Aboriginal peoples had various ecological and ritual relations with the dingo, some of which had been recorded in a haphazard and anecdotal fashion over the past two centuries within the ethno-historical literature. Meggitt, the author of the classic text The Desert People (1962) worked within the historical context of recording the culture of the Warlpiri people of the Western Desert at a time in the mid-1950s when most of his Aboriginal informants had recently emerged from a totally nomadic traditional life into the fringes of cattle station life at Hooker Creek, in the Northern Territory. His detailed account of the relationship between Aborigines and dingoes was doubly important in that not only did it deal with dingoes rather than dogs, but also with Aboriginal communities whose experiences and memories dealt with a period when they lived entirely independently of the European world. Meggitt (1965) examined Down's (1960) hypothesis and found it wanting, concluding that while some elements of a relationship of mutual exploitation between the Aboriginal hunters and dingoes existed, there was no evidence to indicate that this was sufficient to cause the domestication of dingoes. Furthermore, in his opinion, tame dingoes contributed relatively little to Aboriginal diet. Clearly whatever relationship there may or may not have existed between man and this animal, had to be explored within domains outside the purely utilitarian (Manwell and Baker 1984: 25152). 


\section{Dingoes and domestic dogs}

We have a potential taxonomic confusion in this debate concerning the relationship between Aboriginal peoples and dogs in the broadest sense, which needs to be cleared up at the outset. This concerns the important differences between dingoes and domestic European dogs though both animal categories are within a single species. Dating the arrival of the dingo, a subspecies, Canis familiaris dingo, on the Australian continent, has been a matter of contention for over a century. Early claims of dingo bones within Pleistocene deposits, such as those of McCoy (1882) for Victoria, and by Krefft (1867) for a tooth within bone deposits in a limestone cave at Wellington, New South Wales, have not been confirmed by subsequent stratigraphic research, nor - in the latter case - by chemical analyses comparing the concentrations of fluorine within the tooth with that of indisputable Pleistocene bones found in the deposit (Gill and Sinnott 1973). The absence of dingoes both in Tasmania and on other large offshore islands such as those of the Bass Strait and Kangaroo Island, and on Barrow Island off the coast of Western Australia; all isolated by the post-glacial rising sea some 10000 years ago, is powerful evidence that the animal arrived on the continent later than this time.

During the early 1970s, Mulvaney (1975: 138-43) claimed that the antiquity for dingo on the Australian continent extended back as far as some 7000 to 8600 years ago. This was based on an interpretation by T.D. Campbell and R. Edwards of the excavation at Mt Burr, a rock shelter in South Australia, but a more detailed field re-examination of the stratigraphy at this site by R. Luebbers (1979) has shown that the bones came from a disturbed area against the back wall, unrelated to the reported carbon date, and that their real age was probably only some 1000 years (Gollan 1984: 924). A good indication of the oldest possible date for the arrival of the dingo is afforded by the excavation at the limestone cave of Devil's Lair in the southwest of Western Australia, where a flowstone capping sealed the deposit, with a top date of 5000 years (Balme et al. 1978). Nowhere within the underlying layers, with many thousands of bones of other animals, is there any evidence whatsoever of dingo. The oldest full skeleton of a dingo comes from Mulvaney's own excavation in Shelter no. 6 at Fromm's Landing on the lower Murray River, with a sub-adult animal recovered from a layer dated to between about 3000 and 3200 years ago (Mulvaney 1975: 140). Detail osteological analysis of this specimen by Macintosh (1964) indicated no change in morphology of the species over the past three thousand years. A review by Gollan (1982,1984: 924) of the available Australian fossil material, both from archaeological occupation sites and natural pit traps, indicates numerous finds of dingo remains, extending back to a maximum of about 3500 years ago, the latter date being obtained from Madura Cave on the Nullarbor Plain in Western Australia (Milham and Thompson 1976). His view was that colonisation across the entire continent had been rapid, giving a probable maximum date for its introduction somewhere in northern Australia at about 4000 years ago. These data are of great taxonomic importance since they indicate that, contrary to some previously held views (Clutton-Brock 1969: 307-8), the dingo is neither the descendant of an early domestication event, nor has it a particularly ancient genetic lineage (Gollan 1984: 924).

Concerning origins, there is no convincing evidence of domestic or feral dogs in the neighbouring archipelago of South East Asia or the near Pacific before about 3000 years ago. A partial exception is the island of Timor, with dogs appearing within the archaeological record at about 3000 to 3500 years ago (Glover 1986: 169, 205; Gollan 
1984: 924), some time later than the introduction of both pigs and pottery; and from the limited fragmentary material available, these dogs resemble the dingo. Gollan (1984:924) thinks that the dingo probably did not come to Australia by some gradual regional osmosis from the South East Asian archipelago, but rather more directly with some unknown seafarers from an original source in southern Asia. It was then a fully domesticated dog, similar to contemporary canids in the Indus Valley, and probably biologically derived from the Indian wolf. Within Australia, it became feral and spread independently of man, undergoing in the process, some biological adaptation to predation in dry ecological conditions (Newsome et al. 1980). One probable consequence due to ecological competition was the extinction of the marsupial carnivores, the Tasmanian Wolf (Thylacinus) and Tasmanian Devil (Sarcophilus), which disappeared from the fossil record of the mainland Australian continent by about this time. Another population of wild dog, genetically almost identical to the dingo and sometimes referred to as $C$. familiaris hallstromi or the Singing Dog, is also found in the highlands of New Guinea (Bulmer 1967-68).

Dogs of recognisable European breeds were introduced in the very first days of the British colonies, and there is ample historical evidence that these dogs were quickly adopted by Aboriginal communities living on the edges of colonial contact. These often large packs were also commented upon unfavourably by the colonists, who contrasted this social behaviour with that of themselves, especially members of the privileged class having small numbers of specially trained dogs (Greenway 1998). It is unknown to what extent there was any significant genetic contribution to the progeny of these camp dogs during the nineteenth century by wild dingoes, especially in those situations remote from European settlement (Newsome and Corbett 1982). Nevertheless, as recently as the 1950s there were substantial numbers of Aboriginal people living traditional lives in the Western Desert and indeed also in parts of Arnhem Land, who had not had any, or at least not much, contact with introduced dogs. The classic ethnographic accounts from this period and before, would have referred almost entirely to their relations with dingoes. It is a historical fact that, with open access to dogs, these Aboriginal communities also adopted them extremely swiftly, even in the most traditional contexts. Thus we have in the 1960s and 1970s a set of ethnographic accounts of the role of dogs in these societies, which though still being placed within the economic context of foraging, and involving people steeped in their traditional behaviour and language, nevertheless had been transformed to some extent by a new set of relationships with the introduced animal. We must not forget that behaviourally, there are considerable differences between dingoes and introduced dogs, and that the complex set of relations developed by Aborigines with the latter animal may not of necessity have been the case with the former.

\section{Utilitarian or symbolic?}

The debate within the Australian literature enumerated above has tended to alternate between two poles; the one engaged in assessing what utilitarian role dogs or dingoes did or did not contribute to the hunting capacities of Aboriginal communities, and the other playing down this in terms of intangible emotional, guardianship or symbolic roles. While each author has promoted a particular point of view due to their own research experiences, some interesting convergencies have also occurred. 
Let us take the case of dingoes first. Isobel White (1972) worked with Pitjantjatjaraspeaking people who had been relocated during the late 1950s from their arid homelands in northwestern South Australia to the Yalata Aboriginal Reserve close to the coast of the Great Australian Bight in South Australia, in order to facilitate British atomic bomb and missile range testing. According to White's extensive discussions, the Pitjantjatjara people had never domesticated the dingo as a hunting aid, and in this conclusion she agreed with Meggitt. Hayden (1975: 11), however, in another study took Meggitt (1965) to task for reducing 'the almost universal integration of the dingo among Australian Aboriginal bands to a non-economic status and perhaps to a matter of human whimsy'. He reviewed a range of historical data about the ways in which Aboriginal people had made use of dingoes and dogs for hunting game in arid and semiarid regions and also included his own field observations made at Cundeelee in Western Australia. Hayden thought it probable that the dingo (and by implication, dogs) had occupied an important economic position in Aboriginal society throughout a much more extensive area of the Australian continent than had been suggested by Meggitt. While Hayden regarded this as his most significant conclusion, he also recognised other roles that dingoes and dogs played in Aboriginal societies - for example, as sources of warmth during cold winter nights and as forewarners of attack: points also made by Manwell and Baker (1984: 248). There is archaeological evidence from coastal shell midden sites in New South Wales that over the last 1000 years some dingoes were being incorporated closer into the human social domain, with slight consequent osteological changes perhaps due to selection; and that these dingoes were also given burial within the living site midden deposits, prompting Gollan (1984: 926) to observe that 'the domestication of the dingo by Aborigines can be seen to have been [a] culturally continuous, but biologically episodic process'.

Concerning European introduced dogs, there has been a greater body of direct observational data. Gould $(1967,1968)$ recorded dogs specially trained to hunt kangaroos at Laverton and Wiluna in Western Australia by Pintubi-speaking people, who themselves had only emerged from the desert during the early 1960s. Women used these dogs to hunt, while men used rifles and spears. He argued that this technique with dogs had been developed as a result of recent contact with Europeans. In Gould's opinion, this set of hunting methods was efficient and was gaining in popularity.

White (1972) also documented that European dogs were eagerly adopted at Yalata and had caused radical change in some traditional hunting methods, especially those of women. Hamilton in the same year (1972) reported on the use of dogs among the Jankuntjara people then living at Everard Park in northwestern South Australia. Her article explored many aspects of the human-dog relationship, and she examined the role of dogs as pets, competitors and food providers. Her conclusions were complex but it appeared that while dogs made no significant contribution to the food supply, pups provided an outlet for affectionate nurturing behaviour. In addition dogs were important ritual figures, being depicted in a number of interconnected tjukurrpa or dreaming narratives and as well, they served as reference points for moral homilies about human behaviour (Hamilton 1972: 293).

Kolig's articles $(1973,1978)$ took a more polemical approach than previous contributors to the topic. His point of view, in his own words, leant 'towards a more intellectual emphasis' and in so doing, questioned many of the conclusions reached by 
previous authors. According to Kolig, the Wolmadjeri and related groups of desert Aborigines south from the Kimberley of Western Australia, who 'vaguely share a common cultural background with the Jankuntjara, are emotionally attached to their dogs and the situation Hamilton depicts at Everard Ranges in every respect conforms closely to the one here' (Kolig 1973: 122). In addition, Kolig drew attention to the triangular ambiguous relationship between humans, dogs and the supernatural, and characterised the Aboriginal conceptualisation of the dog as being a rather vicious, dangerous being. The dog, in all aspects and forms, is closely associated with the realm of the supernatural - much more so than any other animal.

\section{Tasmania}

A separate historical case study, namely that of the Tasmanian Aborigines, was examined by one of us (Jones 1970), using nineteenth century historical sources. Unlike on the Australian continent, there were no dingoes in Tasmania, since the latter had arrived after the post-glacial flooding of Bass Strait. Thus the Tasmanian Aboriginal people at the point of European contact at the very end of the eighteenth century were one of the few hunting and gathering peoples of the world never to have known the companionship of the dog. The other prominent example is that of the Andaman Islanders in the Bay of Bengal, to whom dogs were introduced in 1858 (Radcliffe-Brown 1922: 417). In Tasmania, within the time span of only a single generation between 1803 and 1830 and within the cataclysmic context of societal collapse due to the British impact, Tasmanian Aboriginal people made a great effort to acquire dogs, which they used to transform their hunting methods. The situation was complex, with the raids and trading of sealers having by 1830 removed from the coastal regions of northern Tasmania, most of the Aboriginal women, so that their traditional contribution to the chase was under-represented in the ethno-historical literature. Men used dogs, described as 'kangaroo dogs: large, looking rather like well-built greyhounds' (Hiatt 1967-68: 260) to bale up wallabies and in some cases kangaroos against trees, where they were dispatched by hunters using spears or clubs. During the early colonial days, there were also numerous groups of white hunters operating in southern and eastern Tasmania. Some of these were officially sanctioned parties, detailed to hunt in order to supply the early settlement with meat, and others were seeking outlawed escaped convicts and bushrangers. To what extent the Aborigines had gained their dogs and learnt new hunting methods by mimicking the whites is a complex question. The result however was that by 1830, packs of dogs were a ubiquitous feature of Aboriginal camp life. On the Bass Strait islands and on Kangaroo Island, Tasmanian Aboriginal women used packs of dogs to hunt wallaby, a practice which continued at least on Kangaroo Island as late as the 1870s. Jones' conclusion was that the Tasmanian situation indicated the powerful symbiotic relationship that almost inherently occurred between hunters and dogs. It is significant that during the decade after the last of the Tasmanian Aboriginal people had been removed to the government settlement on Flinders Island in the early 1830s, the historian John West recorded that there were large packs of wild dogs, believed to be descended from the Aboriginal dog populations, roaming the forests of the Western Tiers of central Tasmania. Yet these did not survive, their viability being dependent on the human interaction. 


\section{The Anbarra case study}

Our contribution to this debate draws on observations made during long-term fieldwork with the Anbarra Aboriginal community who inhabit land round the mouth of the Blyth River in northern Arnhem Land (Northern Territory). The main study by Betty Meehan and Rhys Jones occurred over a twelve month period between July 1972 and July 1973, and between October to November 1974 (Jones 1980, Meehan 1982). Follow-up observations were done by Meehan from June to October 1978, which were partly related to providing field support for the making of the film Waiting for Harry (McKenzie 1978), at the site of Djunawunya, three kilometres west of the Blyth River mouth, and partly to assess changes which had occurred five years after the main study. The major focus of our research had been towards a quantitative documentation of Anbarra subsistence diet and foraging throughout an annual cycle. We had not focused specifically on the role of dogs except where they impinged upon subsistence activities. However, in our daily journals, we also recorded much anecdotal information about dogs. The specific question of the economic role of dogs had been raised with us in 1979 by Klim Gollan, who at the time was writing his PhD thesis on the dingo in Australia. He circulated a questionnaire to a number of workers who had had experience with Aboriginal communities at the time, and a response was prepared in manuscript form by Meehan and Vincent (1979), which is the empirical basis of the present paper.

Although we found something familiar in all of the articles cited above, we wish to underline where we believe our study has an original contribution to make. Firstly, most of the studies quoted above were done within the context of established settlements, whether government, mission or cattle station. Although the people themselves were all of traditional culture and their memories of life before these institutions were obviously keen, their subsistence economy was nevertheless almost entirely dependent on goods and supplies provided by the broader Australian society, either in the form of direct rations in the 1950s and 1960s, or as State-based welfare payments later on. Some foraging for food was done on a part time basis, but the core residence was within the settlements themselves. Thus there were few ecological constraints in these circumstances, either on the capacities of dogs to contribute to the food quest or conversely to be themselves fed from surpluses. Gould's observations were an exception but, while being extremely important in their own right, were limited in their time duration; the detailed quantitative studies of foraging extending usually over a few days, or at the most a week or so.

\section{The context of our fieldwork}

Briefly, the historical circumstances of our work on the traditional subsistence economy of the Anbarra was as follows. Until the 1950s, the people of central Arnhem Land had had as little contact with the outside world as any Aboriginal group in Australia. A patrol on foot traversing the area was carried out by the Reverend G. Sweeney in 1939 for the Northern Territory Administration, and this showed substantial numbers of Aboriginal people living in the region between the Liverpool and Blyth Rivers under traditional economic hunting and gathering systems. In 1947, a small government trading and supply post was set up for the duration of that dry season, at a place called Maningrida on the east bank of the Liverpool River. Within a few weeks, Aboriginal people had flocked to this from the entire region to take advantage of the supplies of 
flour, sugar, tea, and above all tobacco, and also out of curiosity. In 1957 a settlement was set up at the same place and although originally the aim had been that this would only provide trading and medical services, leaving the bulk of the Aboriginal population 'in the tribal areas with a minimum disruption, initially of their tribal patterns' (Patrol Officer Ted Egan in Hiatt 1965: 10), it almost immediately led to the establishment of a township, with almost all of the Aborigines concentrating themselves within it according to their tribal or linguistic affiliations. Hiatt (1965: 11) records that, during a foot patrol to the Blyth River area in June 1958, there were 'only a few people still living in the bush. They said that everyone else was living at Maningrida, on a mission, or in Darwin'.

A decade later, and despite major assimilation both economically and culturally, there were also countervailing tendencies starting to be expressed. These resulted from the fact that many Aboriginal people within Maningrida felt the social pressures of living in a large community of about a thousand people, often in close proximity with other groups who were linguistically quite different, and with whom in the past they may have had ambiguous or even hostile relations. There was also the powerful emotional pull of the lands that had been left, of the ritual obligations that could only fully be carried out through living on them (Tonkinson 1980: 119). This led in the early 1970s, to what has been called the 'outstation movement' (Meehan and Jones 1980: 135-37), whereby substantial groups of Aboriginal people began to leave, either on a temporary or semi-permanent basis, some of the large government settlements and return to their own lands. This was originally directly contrary to the official government policy of 'assimilation' and was accordingly resisted by a variety of official agencies, from education through to health, or even through direct methods of forcible removal. With the election of Gough Whitlam's federal Labor government in December 1972, this was overturned with a reversal of policy towards one of 'self determination' (Coombs 1974, 1980), which transformed the situation entirely.

When two of us (Meehan and Jones) arrived in Maningrida in July 1972, ready to embark on what was effectively planned to be an archaeological study of past Anbarra land use and occupation, we found that the community with which we had hoped to work was established on the eastern bank of the Blyth River at a place called Ngalijibama, where for a period of several months they had been preparing for a major Guna-biba ceremony. Here they were supporting themselves almost entirely by hunting and gathering for their own foods, with minimal support from 'European' sources. At the conclusion of the great ceremonial events, many of the participants stated their intention to maintain their occupation of their traditional lands and accordingly we were invited to remain with them, which we did over a period of twelve months, when we attempted on a daily basis to document their foraging system over an annual cycle.

During this period from July 1972 to July 1973, we lived within a core band community of about 35 people and moved with them through a series of seasonal camps (Meehan 1982: 26-41). There were other related Gidjingarli-speaking groups totaling about 100 people, who carried out their own patterns of seasonal foraging, sometimes connecting with us. During this period, all of the meat and fish in the diet was obtained by hunting. Concerning carbohydrate foods, supplies of flour and sugar were brought in to the community every two or three weeks, though during the full wet season, there were no external supplies for periods of about a month. The women spent a considera- 
ble amount of time collecting vegetable foods and fruits and at some periods of the year this constituted a significant proportion of the carbohydrate dietary content (Meehan 1982: 49-51). We did not fool ourselves that this, by some wave of the temporal wand, was 1872. The Anbarra used metal knives, iron tips in their fish spears, nylon string in the weave of some of their fishing nets, metal fish hooks, and a few shotguns. Yet both we and they felt that what we were experiencing had profound resonances with the pre-contact past, which for most of our older companions had only occurred within the midpoints of their lives. Our fundamental research aims were to try and document Aboriginal foraging activities in quantitative terms, rather than, with the exception of the pioneering Arnhem Land study in 1948 of McCarthy and McArthur (1960), what had usually been expressed in general qualitative accounts.

Other studies of a similar nature to ours, carried out in Arnhem Land during the same period, were those of Jon Altman (1987) with the Gunwingku people southwest of Maningrida and Nic Peterson and, following him, Neville White, with the Ritharrngu people living near the southeastern edge of the Arafura Swamp. Our perspective now, after the passage of 25 years, is that these studies will never again be repeated. The processes of cultural change have been such that even around Maningrida, with the granting of full land rights and the freedom to occupy and exploit traditional lands, systematic foraging for subsistence is no longer carried out except on a minor scale. Our journals therefore document a passing phase, half frozen as it were in the lens of history. Frank Gurrmanamana, with whom we worked closely and in whose extended hearth we lived, said it directly when he chastised us sometimes for not documenting fully his accounts of the past - 'More better you book 'im down straight'.

\section{Linguistic classification concerning canines}

The Anbarra speak a dialect of the Gu-jingarliya (Gidjingarli) language, the term being derived from 'those with the tongue'. Other dialect groups were the Martay, living in the inland eucalypt forest on the east of the Blyth River and the Gulala along the eastern coastline as far as Cape Stewart. A related dialect to Gu-jingarliya was Gun-nartpa, spoken by people on the southern edge of the Blyth River plains and in the woodlands beyond. These peoples collectively were referred to by their neighbours as the Burarra (Meehan 1982: 12-14). The major linguistic study has been that of David and Kathleen Glasgow, culminating in the latter's Burarra-Gun-nartpa Dictionary (1994) and, while this was based on the Gun-nartpa dialect, we have mostly followed her orthography in this paper except where some proper names have become established previously in the literature. Gu-jingarliya is one of the ancient non-Pama-Nyungan languages of northwestern Australia, and has a pre-fixing grammatical structure with four noun classes (Evans and Jones 1997).

The general Anbarra term for dog which we recorded is kulakula, or in the Glasgow orthography (1994: 296) gulukula. This includes all categories of dog including the dingo. Martay people call them wartunga (op.cit.: 673), but both terms are mutually understandable by all groups. We do not know the etymology of either of these terms. The animal is within the an- or masculine noun class. Arnhem Landers classify the natural and human world into two moieties Yirritjinga and Djowanga (cf. Yirritja and Dhuwa of northeastern Armhem Land) and the dog, including dingo, is within the Yirritjinga moiety. In the Glasgow dictionary, a key word is often usefully introduced 
within a sentence that epitomises its context. Concerning gulukula, they were described as 'the dogs [that] always eat the crumbs that fall when the owner is eating' (op.cit.: 296).

Dingoes and wild dogs are also specifically referred to by several other terms which are etymologically interesting. The Anbarra call them an-gugurkuja (op.cit.: 43), which is derived from the verb stem -gurkuja, 'to be frightened' or -gugurkuja, 'fearful one', and refers to their being afraid and running away from people on contact in the bush. Another common name is an-mugat which comes from the noun stem -mugat, 'wild animal or beast'. This can on occasions also refer to a wild, solitary or even a dangerous man, an outlaw, whereas in the feminine noun class of jin-mugat it applies to an unruly woman, one out of social control. The same class of meaning is behind the Gunnartpa term for dingo an-mugarla literally 'he in the bush' derived from -mugarla, 'belonging to the bush, or the jungle' (op.cit.: 50). It can be seen from these terms that camp dogs and dingoes are conceptually within different entities, the former belonging to the domestic world and the latter being within the wild domain of the bush, only fleetingly impinging on human society.

\section{Dingoes and people}

As in the rest of Arnhem Land, myths exist about the arrival of the dingo, and a consistent theme is that this proceeded from the east. For example the Ganalbingu people believe that a series of sacred waterholes located on the eastern side of Arafura Swamp were made during the 'Creation Time' by the ancestral dingo spirit Watu, of the Yirritja moiety, who, travelling from the east, arrived at the place of Ngaliyindi and created there a series of waterholes, a mountain and a cave; the latter being the home of the ancestral flying fox, Warrngu (Djurritjinni 2000). In the Blyth River area, the dingo myth is associated with some low, tidally-exposed mud islands called Ngandi-nginyanginya just off False Cape Stewart. On Anbarra territory itself, in a Yirritja estate, there are several large, discrete shell middens, said to have been formed by Gulukula.(Meehan 1982: 172). These, consisting mostly of the open sea shore bivalve Dosinia juvenalis, are situated on a small fossil inland dune, some $500 \mathrm{~m}$ south from the present coast and separated from it by a further complex of sand dunes which incorporate most of the named sites of the important Djowanga moiety site of Djunawunya (Hiatt 1982). Radiocarbon dates on the most prominent of these Gulukula Mounds indicate that it was accumulated between 900 and 650 years ago.

In some parts of Arnhem Land, the dog also, as opposed to the dingo, has been incorporated into the mythology. Thompson (1949) recorded in northeastern Arnhem Land in the 1930s major ceremonial activities associated with the departure of the Macassan fleets after the trepang or bêche-de-mer season. These ceremonies not only depicted the mali or spirit shadow of the Macassan anchors, which came to signify the departure of the spirits to the realm of the dead (op. cit.: 36), but also effigies of the dog, as in the totem of the Mildjingi clan.

We did not hear much discussion about dingoes competing with people for food though on a couple of occasions when we were part of a goanna and long-necked turtle (Chelodina sp.) gathering expedition, people pointed to empty turtle carapaces saying that the dingoes had beaten them to it! We were told that in the past wild dingo pups were sometimes captured from the bush and brought into the camp, though it was 
added that normally they ran away when they grew up. It was said that the sire of a large ginger-coloured dog, Belk (the name of a coarse grass which grows on coastal sand dunes), had been a dingo but we observed no such intermixing of wild and camp populations. It would be extremely difficult for a dingo to enter an Aboriginal camp without everyone being alerted to its approach by a cacophony from angry, frightened camp dogs. Camp dogs tended to stay in the camp or close by their masters if they were out on hunting trips and people were anxious that their dogs not be left behind in the malpi (bush) because they were afraid that the 'wild dogs' would kill them.

We have never heard dingoes being referred to as untrustworthy nor have we heard them described as being tricksters. There is a hint, however, that people had a certain respect for them. Frank Gurrmanamana said that neither he nor any other Anbarra person would ever shoot a dingo, but it was said, perhaps as a form of slander, that other unspecified Aborigines did. We heard of no stories about dingoes killing people or babies.

\section{Anbarra dogs: numbers and ownership}

Men, women and children owned specific dogs. Men tended to have one, usually a male, which they fed and kept in reasonably good condition, many even having collars, which conformed to police regulations at the time in Maningrida, and they were devoted to their masters. Women tended to have many dogs and although the occasional key hunting dogs were well-cared for and healthy, most dogs kept by women were underfed, miserable looking creatures. A few elderly women, who sometimes owned large numbers of animals, made an effort to give them water and a little food each day. This might consist of some mullet when the catch had been good, or on one occasion a cooked yam which was refused by the dogs. The ordinary camp dogs, however, had to scavenge for their food: scraps thrown to them or grabbed from the hearth, and bits and pieces collected from the low rubbish dumps that surrounded each cleared household area. We have also seen them eat faeces of both human and dog. To protect food from dogs, it was stored on rectangular platforms about $1.5 \mathrm{~m}$ high called belabela. These structures were also used as shades, people sitting and cooking under them during the daytime.

On average, each woman owned about three dogs. A pack of more than 12 dogs was attached to a group of Gulala women and children who lived by themselves at a coastal site close to Cape Stewart. At one stage, a male relative resided with this group but only for a short time. These people were said to have kept such a large number of dogs as a protection against malevolent spirits or the threat, either real or imagined, of dangerous human strangers.

The number of dogs in a camp varied over time. A census taken at the Anbarra home base, Kopanga, on 3 November 1972 indicated that 94 people were in residence, namely 40 adults and 54 children. Between them, they owned the unusually modest number of 14 dogs. Seven households had no dogs at all, six had one, two had two, and only one household had four. At the wet-season site of Lalarr-gujirripa on 5 February 1973 there were 13 adults and 22 children living there - a total of 35 people. There were also 20 dogs, namely six adults and 14 pups, the number of dogs per household ranging from one to seven, with two households claiming to own five dogs each. 
Children adored pups, some owning two, and they often cried or threw tantrums when a new litter appeared in the camp if a new pup was not given to them. Usually the parents, already had 'too many dogs', but in the end, children had their own way and a new pup became part of the household. Much affection, attention and food was lavished upon pups by children (and often by adults too) but this usually slackened off as the animals reached maturity. It was our belief that people were attracted by the 'puppiness' of the young animals. When that disappeared and they became merely 'dogs', their owners tended to lose interest in them and they were left to take their chances within the rest of the dog population. They still tended however, to concentrate their scavenging and other activities around the natal hearth.

Some responsibility was associated with the ownership of dogs. If a dog was fighting in the camp or stealing food, it was expected that its owner would stop it and perhaps make recompense for any losses. If someone was bitten by another person's $\mathrm{dog}$, apologies and/or compensation were usually forthcoming. On one occasion at Gupanga, a dog bit a brother of its owner. This was considered to be so serious, though in fact the wound itself was minor, that a small ceremony was organised to make the incident 'all clear'. The owner of the canine culprit sang his own song cycle one evening after dinner, especially for his injured brother and apparently that was the end of the matter.

\section{Population and breeding}

Most Anbarra dogs were the offspring from populations that had lived in the community for some time, being derived largely from Maningrida, missions or other settlements. We do not think, however, that they were traded in the real sense of the term. Normally they were gifts given to someone, from a close relative or, if the recipient was an important man, by men of similar stature in another community; like most Anbarra gifts, they also signaled reciprocity sometime in the future. At the time of our fieldwork, there was developing a preference for formal 'European' breeds, especially those brought in from Darwin. This, we believed, was based almost entirely on the fact that these animals were usually bigger and healthier and that, initially at least, they lacked the nasty characteristics that many camp dogs seemed to develop. People said of such dogs that they were an-mola ('good') though we rarely saw them go hunting. The opposite to these were 'rubbish dogs' or an-bachirra, a term often ascribed either to other people's dogs or dogs that were in particularly poor health, which stole food from platforms or which were savage.

The 'breed' dogs tended to survive longer because they were cared for more than the camp dogs but also they tended not to maintain their original health and vigour once they had taken up residency in an outstation camp. The majority of camp dogs were small and skinny. Many had chronic 'mangy' skin complaints, some having no coats left at all. These unfortunate creatures spent most of their time whining and scratching. Many dogs had 'diseases', the details of which we know little, which caused their genitals and anus to become raw red in colour, protrude and secrete pus. Their eyes too, were red and watery, and diarrhoea was one of their common ailments; so also was heart worm.

Fights involving any number of dogs from two to twenty were common features of camp life. These tended to occur when bitches were on heat, but also when dogs 
belonging to particular households trespassed into the territory claimed by others. There appeared to be no system whereby a certain male dog was mated with a particular bitch. Occasionally, we saw a bitch on heat tied up or in some way protected from rampant males, but this was usually a half-hearted affair. When unfortunate animals became stuck in the act of copulation and were mass-attacked by other males, people made some desultory efforts to protect the pair by throwing water on them, but ultimately such events were considered to be highly amusing.

When bitches gave birth to large litters of pups, no genuine attempt was made to destroy any of them. One of Nancy Bandeiyama's bitches had a litter whilst we were camped at Djunawunya in 1978, and because her household already owned a large number of dogs (15-20), she felt that she should get rid of the new arrivals. Instead of hitting them on the head or throwing them into the sea, she carried them several kilometres east along the beach and left them there, no doubt hoping that some other agent would dispose of them. Next day the mother dog had carried them all the way back to the camp and the matter lapsed. Pups seemed to be chosen from litters for reasons such as colour, fatness, liveliness, or because they reminded their owners of some of their totems. However, the offspring of two good hunting dogs, Manyjaparna and Andirrbula, were sought after.

Some dogs died at birth either because they were unhealthy or because one of the male dogs bit them on the head. Others died because they were struck by venomous snakes or taken by crocodiles. The hunting dog An-dirrbula died because she ate the contents of a tin of baking powder. A balanda (European) friend of her owner explained how this could be relieved by piercing her stomach with a metal skewer, but she was not treated and subsequently died. Some were beaten so severely, usually by their owners but sometimes by angry relatives, that they died from wounds. We know of one dog that received a heavy welt across the spine with a big stick, because it was instigating fights in the camp. It later died, its owner insisting that he would retaliate one day and kill a dog belonging to the person who had wielded the fatal blow. We did not hear that this revenge had happened before we left the field.

The Anbarra attitude towards their dogs was an ambiguous one. So often they were talked of as pests and most of them, according to Western norms, were underfed and roughly treated; but still no concerted attempt was made to control their numbers. In a sense, for most of the creatures it was a contest for survival when they competed with the rest of the camp dogs for food and sexual gratification.

\section{Training and caring}

We were told that pups chosen to be hunters were trained by having their noses rubbed in the urine of intended prey - for example, goanna. We saw this done once at Lalarrgujirripa in 1973 but were unable to follow the performance of the dog which had undergone this treatment. Frank Gurrmanamana once applied liquid squeezed from the anus of a wallaby to An-dirrbula for the same purpose.

When people moved camp, all the dogs were encouraged to accompany the group. Everyone called them to come and generally returned to get them if they did not respond. On our way along the beach to Wayal, about $10 \mathrm{~km}$ east of the Blyth River mouth on 13 July 1973, we had dogs with us. Some of them were pups and when they became tired, as they did frequently, they slumped down, panting heavily and looking 
as if they intended to stay exactly where they were. Unfortunately, at the time, we were not carrying water and so could not revive them that way. However, inevitably, they were picked up and carried. In July 1978, when people moved from the Nakarra site of Gorrng-gorrng in eucalypt woodland just west of Anbarra country to the coastal site of Djunawunya for the mortuary ceremony that was to be held there, there was no room in our vehicle for all of Nancy Bandeiyama's dogs. The next day she returned to Gorrng-gorrng and walked back with her dogs - a round trip of some $12 \mathrm{~km}$. Rarely, some dogs which were in ill health and too weak to follow were left behind in a vacated camp. It seems that these did not turn feral and hunt for themselves but stayed very much within the confines of the camp. If they were not retrieved by their owners they would die. Several dogs left at the deserted home base Kopanga were extremely thin, their rib cages protruding noticeably, and exceedingly weak. They had managed to climb onto some of the platforms in the camp on which people had stored canvases and food. There they had eaten everything they could find including soap and tea leaves. When we moved back to this site two months later, these dogs were nowhere to be seen and presumably they had died. Nobody seemed to be particularly concerned.

\section{Hygiene issues}

Dogs were not considered to be cleaners of camp sites, although they acted as agents in scouring the ground for discarded bones, fish skins and other food scraps. They defecated and urinated whenever and wherever they pleased, though they were usually chastised if this involved areas close to the hearth. We noted at Kopanga in 1978 that many dogs tended to excrete on the curvilinear piles of rubbish which were swept to the periphery of hearth areas, but this was by no means universal. People conceded that some of their camp dogs were dirty and may have had a role in the transmission of lowgrade infections such as eye irritations and intestinal complaints, especially amongst infants, but they did little to improve this situation. They would not use fresh water holes in which dogs had been known to swim until the well had been scoured out and clean water was flowing freely. Some people would throw all of their dogs into the sea water every now and again to 'clean them up'. Coastal people, obviously seeing salt water as a cleansing agent, also maintained that their dogs were healthier than those belonging to inland groups because hinterland dwellers could not force their dogs to swim in the sea.

\section{The role of dogs in the food quest}

Dogs accompanied most hunting and some fishing expeditions which we observed, yet only a few individual dogs captured any animals on most of these expeditions. Dogs were most useful for hunting the lizard-like goannas (Varanus spp.) when tall green grass covered the inland sand dunes and large earth mounds, formerly formed by jungle fowls, in which the goannas had dug their burrows. When women hunted goannas and feral cats, they used the dogs to flush prey from the long grass. They completed the task by digging reptiles out of holes or pulling cats from trees, then stunning or killing them with digging sticks or logs.

On 8 December 1972, after about a month of rain which came from the southeast before the wet season proper began, one of us (Meehan) accompanied a goanna hunting expedition: 
As we moved on to one of the yarlinga [inland fossil sand dunes] two metres high, I saw for the first time, dogs being used for hunting... Nancy and Frank walked behind the dogs urging them on with the words 'ma! ma!' ['go! go!']. The dogs, surprisingly, responded in a well-disciplined way - the idea being, I suppose, that the goannas were now out of their holes and walking about and the dogs could find them and bail them up.

Dogs rarely killed the animals they bailed up or pinned down with their paws. They were actively discouraged from doing so by the Aboriginal hunters. On the expedition described above, the hunting dogs found a dying goanna. Meehan's companions did not want the reptile for food - it was too old and thin. The dogs snapped and snarled at it and made attempts to bite pieces from its tail. They obviously wanted to eat it but had no idea how to go about it. The Aborigines made no attempt whatsoever to kill the animal and cut it up for the dogs either.

During our fieldwork, we recorded those instances where named dogs were said to have caught items of prey, though it is probably more accurate to say that they had been responsible for flushing animals out and holding them captive until the Aboriginal hunters secured or despatched them. Animals captured by dogs were goannas (74 or $90 \%$ ), blue-tongue lizards ( 6 or $7 \%$ ) and feral cats ( 2 or $2 \%$ ). Seven dogs were specifically named as successful hunters, and five more dogs were said to have helped in the capture of goannas. This meant that 12 dogs were actively involved in the procurement of 82 animals, approximately seven per $\mathrm{dog}$. This calculation is misleading, however, as one dog, An-dirrbula (Plate 1), made an outstanding contribution, catching 48, including all of the blue-tongue lizards and feral cats.

A rough estimate of the number of animals caught by each named dog is as follows, together with the meaning of the dog names.

\begin{tabular}{llc}
\hline Dog's name & \multicolumn{1}{c}{ Meaning } & No. of animals killed \\
\hline An-dirrbula & shellfish, Dosinia juvenalis & 48 \\
Manjaparna & mudflat & 10 \\
Chilba & silver & 7 \\
Yelabeli & yellow belly & 3 \\
Minijarraura & - & 2 \\
Mipaldata & eye of something & 2 \\
Happy's dog & - & 1 \\
\hline
\end{tabular}

Nine other animals killed were procured by five unspecified dogs.

Even if it were not intended that they hunt, one or more dogs almost always accompanied foraging groups. This was especially true for groups of women and children but held as well for family expeditions. Women setting off on foraging expeditions to procure goannas, fresh water turtles, shellfish or yams always called their dogs to accompany them. This was similar to making sure that they took their dilly bag, tomahawk, matches and digging stick and in this sense, dogs were an essential part of women's foraging equipment. Dogs were specifically encouraged to accompany women shellfish gatherers to the beds, particularly when it was likely that they would be working for some of the time at least in knee-deep water as the tide went in and out. The dogs barking and cavorting in the water were said to keep the sharks away. People 
said that dogs sometimes caught small fish in the sea and certainly we have seen them engaged in that pursuit, but we never saw them catch anything.

We recorded the number of dogs that were taken on 18 foraging expeditions. In fact, only two or three expeditions without dogs were noted by us. The average number of women and children on these expeditions was about eight (groups ranged from one to 23). The average number of dogs per trip was about five (groups ranged from one dog per ten people to two dogs per person). When groups crossed the Blyth River estuary mouth in dugout canoes for a day of foraging on the eastern bank, some 'hunting' dogs accompanied them but more frequently the canoes were overloaded with people and so most dogs had to be left behind. Despite being instructed to remain on land, they would follow the canoe by swimming over the river. That we never saw one taken by a crocodile was a constant surprise. When people were returning from a Guna-biba ceremony at Yinangarnduwa near Cape Stewart in December 1972, they crossed the river in a canoe but there was no room for their old dog, Minijarraura. It turned up the next day, having swum the river at its mouth where it is almost one kilometre wide. People talked of this event with interest and the dog, despite its nasty temperament, was admired for its stamina and bravery.

When men went on a focused hunting expedition, either singly or in small groups (rarely more than two), in order to get wallabies or large waterbirds, they sometimes took a dog with them -- one that could be relied upon to be obedient and quiet. More often, however, they hunted without dogs. Anbarra men at that time were learning to capture the feral water buffalo (nganaparra) which were increasingly encroaching onto the Liverpool and Blyth River wetlands from western Arnhem Land. Normally, they did this with the aid of vehicles and what small calibre guns that they had available 0.22 rifles and shotguns. Only a few Gun-nartpa men to the south had a licence to own 0.303 rifles, which are the most effective weapon against these large beasts, and which they had learnt how to use from experience working with balanda professional buffalo hunters in the Alligator Rivers region to the west. When vehicles were not available or were unusable because of flooded mud flats, Anbarra men hunted on foot and experimented with dogs, encouraging them to 'round up' the buffaloes so that armed hunters could shoot them from close range. We saw one dog involved in this strategy but on that occasion the hunters failed to bring down the buffalo.

\section{Dogs as a food taboo}

To our knowledge no camp dogs or dingoes were ever eaten. In fact, Frank Gurrmanamana was horrified when we suggested this hypothetical possibility. He said that the Anbarra could not eat gulukula because they were a 'friend' and that if they did, they would 'vomit'. He did say that it was reported that the people from Melville Island ate dogs and he expressed his disgust at such a practice. This was really the case of ascription of strange or 'primitive' behaviour to a distant, half-known people. We should add that the Anbarra do hunt and eat feral cats (jin-mugat, bujibuji cf. 'pussy-pussy') and regard their red flesh as excellent. As yet, only a few cats were kept as pets in the camps, but it was becoming a more common practice, especially in Maningrida. (It will be interesting to see if attitudes towards the eating of cat flesh grow more like those pertaining to dog flesh if cats become gradually assimilated into Anbarra camp life as pets.) 


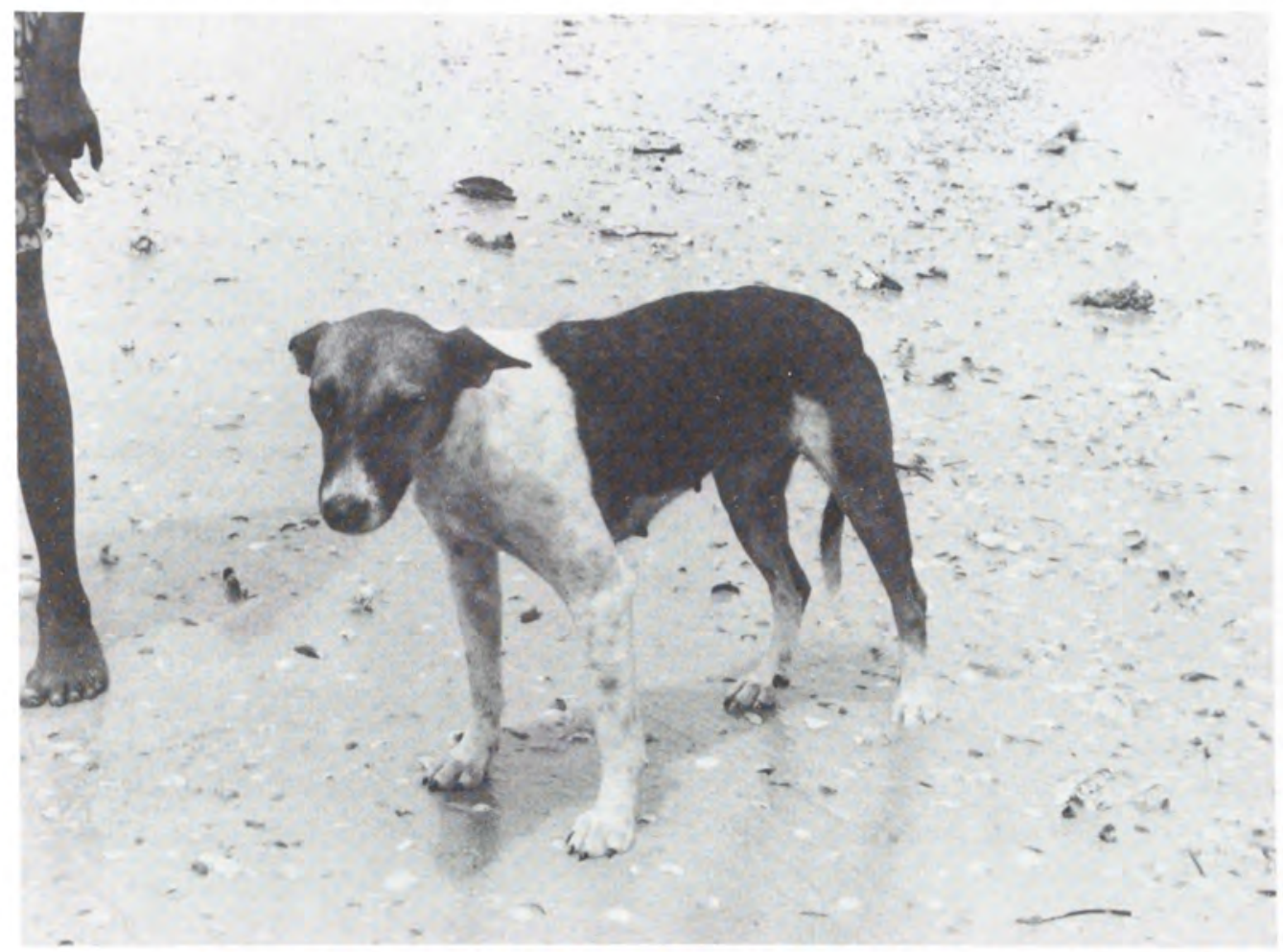

The dog belonging to Nancy Bandeiyama (now deceased) - An-dirrbula, the canine hunter. (Photograph courtesy of the Meehan and Jones collection)

Another similar case which is as yet unresolved concerns pigs. These were unfortunately somewhat irresponsibly introduced to Maningrida in the late 1970s by Tongan Methodist missionaries, and some quickly became pets of Aboriginal households. Inevitably some of their progeny became wild, and these have by the late 1990s established growing feral populations, whose ecological depredations on the Blyth River wetlands and further to the east at the mouth of the Arafura Swamp are causing considerable concern among land managers (Finlayson et al. 1999) and increasingly to Aboriginal people themselves. Programs have been put in place to shoot them as part of vermin control. The Anbarra to whom one of us (Jones) talked about it in July 1999 were wary of eating pig meat, partly because it was strange and partly because many animals were said to be infected with communicable diseases such as tuberculosis. However, at an outstation in Djinang country on the western edge of the Arafura swamp, a group of Anbarra men were seen butchering and carefully inspecting the meat of a wild pig which they had shot. They sliced some pieces and grilled them. The taste and smell were said to be 'too sweet', though one man volunteered that the meat was a bit like 'bacon' which the balandas or white people bought in the supermarket. The meat was gingerly eaten, and whether this was because of its novelty, or because pigs for the previous decade or so had been pets in many Anbarra households, is not known.

\section{Guard dogs}

Anbarra people believed that the bush was potentially inhabited by dangerous forces, both human and supernatural, and that they must be on the alert for them at all times. 
This was especially true for women and explained why they rarely went hunting alone but usually as part of largish groups, and why they nearly always had dogs with them. Men felt less vulnerable. On a purely utilitarian scale, dogs were useful to warn about snakes or other animals around the camp sites. As soon as night fell, people rarely left the glow of camp fires because, for them, the darkness was full of potential malevolence. Occasionally, some noise or movement would disturb the sleeping dogs. They would instantly leave their camp fires and run towards the origin of the disturbance. There they would take on a rigid stance and begin to bark and growl, creating a most memorable din. People usually interpreted these outbursts as the dogs' responses to the presence of spirits, wangarra or the ghosts of dead relatives. There was also the issue of a 'murder man', either conceived of literally as an enemy with some hostile intent, but more generally as a person with supernatural powers to commit ritual murder. It must be remembered that in general, except in the cases of small babies or very old people, deaths of individuals through illness were not considered to be due to natural causes, but to some form of sorcery. The Anbarra name for a such a sorcerer is an-muragalk, the term being derived from -ragalk, a thin long bone point made from the fibula of a wallaby, and believed to be inserted behind the upper left rib cage of a victim while asleep or otherwise not conscious, and so killing him by piercing him in the heart. Dogs were considered to have special powers which could sense the presence of such dangers and alert humans to it before they themselves were aware of it.

The dogs also reacted in the same way when a buffalo came near the camp, usually to drink from the camp waterhole. Any innocent visitor would get the same reception if they arrived unexpectedly late at night. If such a person had not remembered to alert the community of his impending arrival, and to arm himself with a stout stick, he might well be severely savaged by the mangy sentinels of the night.

\section{Emotional support}

It is clear that for some members of the Anbarra community, dogs and especially pups fulfilled an important emotional role. Every Anbarra person loved 'puppies', and, as far as we could interpret, treated them tenderly as if they were human babies. They forced food upon them, cuddled and talked to them, slept with them and carried them around. They pinched and pummeled them in order to get a response from them in much the same way as they did with small babies and toddlers.

On the other hand, Anbarra women, usually middle-aged to old and widows, but sometimes older wives from polygamous marriages, had a special relationship with their dogs. One woman we knew was the older wife of a senior Anbarra man. This man was her second husband; they had one son. When her first husband died, she and her younger sister became the wives of their present husband. This man, as long as we have known him, regarded the younger of these two women as his 'really' wife - his pal and his companion, though he has always treated his older wife with respect. However, the older wife was not altogether happy with her lot. She fought frequently with her sister and her husband, and often complained that her relatives were not looking after her as they should. She bemoaned the fact that her only son spent little time with her and even more infrequently sent her food. This woman owned a large number of dogs (about ten) and she spent most of her time with them. If she went to the waterhole or to a 'dinnertime camp', they went with her. They slept beside her at night and sometimes one or 
two of them joined her and her sister's daughters (who always slept with her) inside the mosquito net. This woman spent a considerable time during each day sleeping and at night was somewhat of an insomniac. Many times we were woken during the early hours of the morning, when the camp was usually quiet, to hear her having an animated conversation. It took us several such experiences to realise that she was talking to her dogs. They were totally devoted to her and always sat up and pricked their ears when she addressed them. This was not surprising, for she fed and watered them every day. When one of her bitches gave birth to a litter of pups she constructed a small domeshaped shelter from cloth - similar to those that were built for Anbarra women when they were about to give birth to a new baby - to house the mother and her offspring. This is an exceptional example of the relationship that some women had with dogs but it clearly supports our belief that dogs can sometimes be substitutes for kin and dwindling responsibilities.

\section{Dogs as warmth}

Within this tropical region we never saw dogs used specifically as blankets and, unlike central Australia, there are no freezing temperatures even at the depth of 'cold weather time'. Some dogs were permitted to sleep inside mosquito nets with their owners but these were usually pups. The rest of the animals remained outside formal sleeping areas, usually resting around the hearth belonging to their owners. By morning time, if the night had been chilly, they could often be seen sleeping on the ashes of the hearth.

\section{Material culture}

We did not see or hear about any part of a dog, such as teeth or bones, being used in the manufacture of an artefact. Sometimes, however, dogs wore artefacts themselves. Necklaces were made from land snail shells and painted with white clay. These were placed around the neck of a dog for night hunting. The hunters could see the white shells in the dark but, more importantly, they could hear them rattling as the dogs pursued the prey. We never saw this hunting technique used but we did acquire one of the necklaces.

\section{Disposal of deceased dogs}

We saw no dogs cremated or placed in trees after they had died. However, the Anbarra had begun to bury their dogs in graves. On one occasion, Meehan asked if she could have the skeleton of one of the dogs which was said to have dingo ancestry for osteological examination by K. Gollan in Canberra. After some hesitation, this request was agreed to. The dog had been rolled in paper and cardboard and buried in a metre deep grave. People watched the disinterment with great interest, examining everything that came out of the grave and naming the bones. Analysis indicated that the animal was totally of European origin with no dingo ancestry. As promised, the remains were returned soon after, and when last seen were stored in a plastic bag, on top of a domestic platform.

\section{Concluding remarks}

To return to our central question, it is undoubtedly the case that a few dogs, well trained and with a particular aptitude for the task, were a great aid in hunting. This was not only in their direct contribution to the chase as we have documented, but also more generally in providing some kind of a screen for hunting parties, in flushing out game 


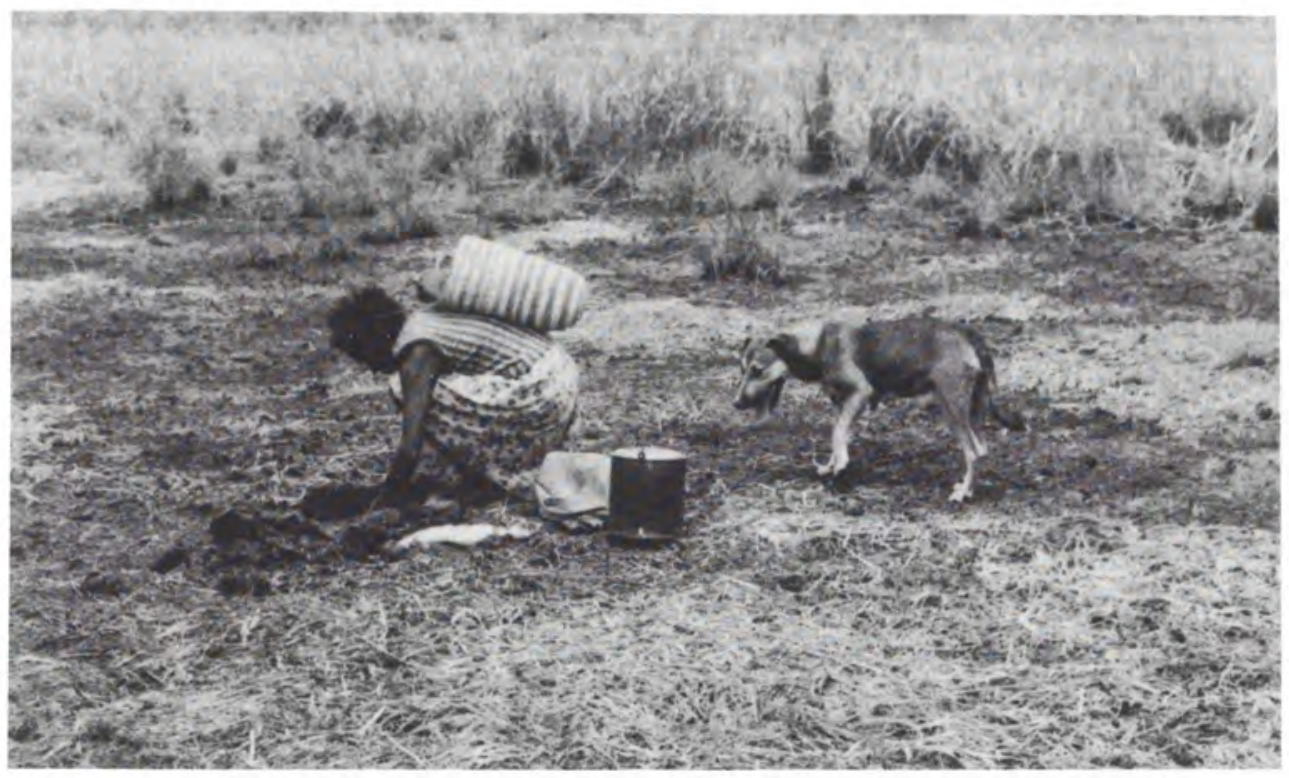

The dog Manyjaparna with Nancy Bandeiyama (now deceased)

who is collecting gulach, the sweet spike rush (Eleocharis dulcis) from the black soil plains behind Kopanga during the late dry season of 1972

(Photograph: Meehan and Jones collection 1972).

and alerting to snakes and other potential dangers. This was particularly true of women, who seldom embarked on any foraging expedition without the accompaniment of dogs. These good hunting dogs (Plates 1 and 2) were well looked after and fed. However there remains the essential problem that the bulk of the dog population in Anbarra camps was absolutely hopeless at hunting. Not only did the dogs not make any direct contribution to the products of the chase, or hunt on their own accord, but also they were net consumers of the total amount of food in general circulation. What, therefore, was their role or, as we have put it elsewhere (Meehan and Vincent 1979), 'why so many?'

The answer to this question resides in two main roles that dogs played in Anbarra society. The first was as sentinels and guards. We have briefly outlined and explored this in both the prosaic and supernatural domains. The latter cannot be underestimated. Having a large community of dogs gave to the Anbarra people a sense of social space and security which extended way beyond the limits of their cleared camp areas or their parties as they travelled through the country. In this context it is interesting to note that the propensity of barking in European dog breeds may have been a specifically selected trait in the early domestication process (Manwell and Baker 1984: 244) and of course the dingo, by contrast, is noted for its relative silence. The other major role was to provide companionship and to be objects of affection. Again this was particularly noted in the case of both children and women, especially elderly women.

The Anbarra liked owning and being surrounded by large numbers of dogs. We are conscious of the fact that in this case study, there were no particular constraints due to food shortage, since the supply of basic carbohydrate in the form of flour and sugar was available from the Maningrida settlement base. This was particularly the case dur- 
ing our later fieldwork in 1978, when the largest numbers of dogs were recorded. During such 'fat' times, there were few external limits on dog population levels and the Anbarra did not exercise any obvious controls on them. During times of hardship, however, we believe that things would be quite different. It is highly likely that the bulk of any dog population would have been left to its own resources, and in situations of forced mobility due to food shortage, abandoned at old camp sites, with probable death due to starvation. Our model of a stochastically fluctuating population profile is how we envisage the situation, had dogs been introduced into Anbarra society, say in the nineteenth century, away from the confines of the broader European system.

Our study presented here, partially stimulated by Sally White's own pioneering contribution from the other side of the continent, adds to an empirical body of data concerning Aboriginal relations with dogs. Apart from their own intrinsic interest, we believe that these studies potentially provide great insights into the processes that led to the initial domestication of the dog which might, given the emphasis of this paper, appropriately be termed as woman's best friend.

\section{Acknowledgements}

Without the support and total cooperation from the Anbarra community, this work could not have been carried out. We thank them all, but especially Frank Gurrmanamana, Nancy Bandeiyama (now deceased) and their family.

The manuscript document (Meehan and Vincent 1979) lodged in the library of the Australian Institute of Aboriginal and Torres Strait Islander Studies, Canberra, contains further specific field data not used in the present paper.

Betty Meehan ${ }^{1}$ is an anthropologist who has worked for many years with the Anbarra people of north central Arnhem Land in the Northern Territory. Rhys Jones ${ }^{2}$ is Professor in Archaeology and Natural History in the Research School of Pacific and Asian Studies at the Australian National University, Canberra. Annie Vincent ${ }^{3}$ is an archaeologist who has worked in East Africa and Australia.

\section{References}

Altman, J. C. 1987. Hunter-gatherers today: an Aboriginal economy in north Australia. Australian Institute of Aboriginal Studies, Canberra.

Balme, J., Merrilees, D. and J.K. Porter. 1978. 'Late Quaternary mammal remains, spanning about 30,000 years from excavations in Devil's Lair, Western Australia', Journal of the Royal Society of Western Australia 61: 33-65.

Bulmer, Ralph. 1967-68. 'The strategies of hunting in New Guinea', Oceania 38: 302-318. Clark, J.D.G. 1953. Star Carr. Cambridge University Press, Cambridge.

\footnotetext{
1. 474 Plains Road, Bungendore, NSW 2621.

2. Department of Archaeology and Natural History, Research School of Pacific and Asian Studies, Australian National University, Canberra ACT 0200.

3. 455 Orange Grove Road, Woy Woy, NSW 2256.
} 
Clutton-Brock, J. 1969. 'The origins of the dog' in Brothwell, D. and E.S. Higgs (eds), Science in Archaeology, 2nd edition, pp. 303-9. Thames and Hudson, London.

Colton, H.S. 1970. 'The aboriginal south-western Indian dog', American Antiquity 35: 153-9.

Coombs, H.C. 1974. 'Decentralisation trends among Aboriginal communities', Search 5: 135-43.

Coombs, H.C. 1980. 'Implications of land rights' in Jones, Rhys (ed.), Northern Australia: options and implications, pp. 121-9. Research School of Pacific Studies, Australian National University, Canberra.

Davis, S. and Valla, F.R. 1978. 'Evidence for the domestication of the dog 12,000 years ago in the Natufian of Israel', Nature 276: 608-10.

Degerbol, M. 1962. 'On the find of a Pre-boreal domestic dog (Canis familiaris L.) from Star Carr, Yorkshire, with remarks on other mesolithic dogs', Proceedings of the Prehistoric Society 27: 35-55.

Djurritjinni, Charlie. 2000. 'Wenytjirr (washing) ceremony', in Fifth National Indigenous Heritage Art Award Catalogue. Australian Heritage Commission, Canberra.

Downs, J.E. 1960. 'Domestication: an examination of the changing social relationships between man and animals', Kroeber Anthropological Society Papers 22: 18-67.

Evans, N. and Jones, Rhys. 1997. 'The cradle of the Pama-Nyungans: archaeological and linguistic speculations', in Evans, N. and P. McConvell (eds), Linguistics and archaeology: Aboriginal Australia in global perspective, pp. 385-417. Oxford University Press, Oxford and Melbourne.

Finlayson, C.M., Yibarbuk, D., Thurtell, L., Storrs, M. J. and P. Cooke. 1999. 'Local community management of the Blyth/Liverpool Wetlands, Arnhem Land, Northern Territory, Australia', Supervising Scientist Report 137. Supervising Scientist, Canberra.

Gill, E.D. and Sinnott, P.J. 1973. 'Age of canine teeth associated with giant extinct marsupials at Wellington Caves, New South Wales', Mankind 9: 125-6.

Glasgow, Kathleen. 1994. Burarra-Gun-nartpa dictionary with English finder list. Summer Institute of Linguistics, Australian Aborigines and Islanders Branch, Darwin.

Glover, Ian. 1986. 'Archaeology in Eastern. Timor', 1966-67, Terra Australis, 11. Department of Prehistory, Research School of Pacific Studies, Australian National University, Canberra.

Gollan, J.K. 1982. 'Prehistoric Dingo'. Unpublished PhD thesis. Department of Prehistory, Research School of Pacific Studies, Australian National University, Canberra.

Gollan, K. 1984. 'The Australian dingo: in the shadow of man', in Archer, M. and G. Clayton (eds), Vertebrate zoogeography and evolution in Australasia. Animals in Space and Time, pp. 921-27. Hesperian Press, Carlisle, Western Australia.

Gould, Richard A. 1967. 'Notes on hunting, butchering, and sharing of game among the Ngatatjara and their neighbours in the West Australian desert', Kroeber Anthropological Society Papers 35: 41-66.

Gould, Richard A. 1968. 'Subsistence behaviour among the Western Desert Aborigines of Australia', Oceania 39: 254-280.

Greenway, Emma 1998. 'Ego on a leash. Research in action', Latrobe Bulletin, June: 9. Latrobe University, Melbourne. 
Hamilton, Annette. 1972. 'Aboriginal man's best friend?', Mankind 8(4): 287-95.

Hayden, Brian. 1975. 'Dingoes: pets or producers?', Mankind 10(1): 11-15.

Hiatt (see Meehan), Betty. 1967-68. 'The food quest and the economy of the Tasmanian Aborigines', Oceania 38: 99-133, 190-219.

Hiatt, L. R. 1965. Kinship and Conflict. Australian National University Press, Canberra

Hiatt, L. R. 1982. 'Traditional attitudes to land resources' in R. M. Berndt (ed.), Aboriginal Sites and Rights and the Impact of Resource Development, pp. 13-26. University of Western Australia, Perth.

Ikawa, F. 1964. 'The continuity of non-ceramic to ceramic culture in Japan', Arctic Anthropology 2: 95-119.

Jones, Rhys. 1970. 'Tasmanian Aborigines and dogs', Mankind 7(4): 256-271.

Jones, Rhys. 1980. 'Hunters in the Australian coastal savanna' in Harris, D. (ed.), Human ecology in savanna environments, pp. 107-46. Academic Press, London.

Krefft, G. 1867. 'Fossil remains of mammals, birds and reptiles from the caves of Wellington Valley', Vol. 1, Universal Exhibition, 1867, Sydney.

Kolig, Erich. 1973. 'Aboriginal man's best foe?', Mankind 9(2): 122-23.

Kolig, Erich. 1978. Aboriginal dogmatics: canines in theory, myth and dogma. Bijdragen 134: 84-115.

Lawrence, B. 1967. 'Early domestic dogs', Zeitschrift für Saugetierkunde 32: 44-59.

Long, Jeremy. 1974. 'Aborigines and dogs', Mankind 9(3): 233-34.

Luebbers, R.A. 1979. 'Meals and menus: a study of change in prehistoric coastal settlements in South Australia'. Unpublished PhD thesis, Department of Prehistory, Research School of Pacific and Asian Studies, Australian National University, Canberra.

Macintosh, N.W.G. 1964. 'A 3,000 year old dingo from Shelter 6 (Fromm's Landing, South Australia)', Proceedings of the Royal Society of Victoria 77: 498-507.

McCarthy, F. D. and Norma McArthur. 1960. 'The food quest and time factor in Aboriginal economic life', in Mountford, C. (ed.), Records of the American-Australian Scientific Expedition to Arnhem Land vol. 2: Anthropology and nutrition, pp. 145-90.

Melbourne University Press, Melbourne.

McCoy, F. 1882. 'The dingo, prodromus of the palaeontology of Victoria', Geological Survey of Victoria: $7-10$.

McKenzie, Kim. 1978. Waiting for Harry. Film. Australian Institute of Aboriginal Studies, Canberra.

Manwell, C. and C.M.A. Baker. 1984. 'Domestication of the dog: hunter, food, bedwarmer, or emotional object', Zeitschrift für Tierzüchtung und Tierzüchtungbiologie 101: 241-56.

Meehan, Betty. 1982. Shell bed to shell midden. Australian Institute of Aboriginal Studies, Canberra.

Meehan, Betty and Rhys Jones. 1980. 'The outstation movement and hints of a white backlash', in Jones, Rhys (ed.), Northern Australia: options and implications, pp.13157. Research School of Pacific Studies, Australian National University, Canberra.

Meehan, Betty and Annie Vincent. 1979. 'Every Aborigine loves a dog - but why so many? Some preliminary comments about dogs in the Anbarra community'. 
Unpublished manuscript, 20 pages, figures and plates. Copy lodged in the library of the Australian Institute of Aboriginal and Torres Strait Islander Studies, Canberra.

Meggitt, M. J. 1962. The desert people. Angus and Robertson, Sydney.

Meggitt, M. J. 1965. 'The association between Australian Aborigines and dingoes', in Leeds, A. and Vayda, A.P. (eds), Man, culture and animals. Publication 78, American Association for the Advancement of Science, Washington.

Milham, P. and P. Thompson. 1976. 'Relative antiquity of human occupation and extinct fauna at Madura Cave, southeastern Western Australia', Mankind 10: 175-80.

Mulvaney, D.J. 1975. The prehistory of Australia, 2nd edition. Penguin Books, Harmondsworth.

Newsome, A.E. and Corbett, L.K. 1982. "The identity of the dingo. II. Hybridization with domestic dogs in captivity and in the wild', Australian Journal of Zoology 30 : 365-74.

Newsome, A.E., Corbett, L.K. and Carpenter, S.M. 1980. 'The identity of the dingo. I. Morphological discriminants of dingo and dog skulls', Australian Journal of Zoology 28: 615-25.

Radcliffe-Brown, A.R. 1922. The Andaman Islanders. Cambridge University Press, Cambridge.

Sweeney, G. 1939. Report of survey in the Liverpool-Blyth River region, July-August, 1939. Northern Territory Administration, Darwin.

Thomson, D.R. 1949. 'Arnhem Land: explorations among an unknown people', The Geographical Journal 114: 29-43.

Tonkinson, R. 1980. 'The cultural roots of Aboriginal land rights', in Jones, Rhys (ed.), Northern Australia: options and implications, pp. 111-20. Research School of Pacific Studies, Australian National University, Canberra.

Turnbull, P.F. and Reed, C.A. 1974. 'The fauna of the terminal Pleistocene of Palegawra Cave, a Zarzian occupation site in northeastern Iraq', Fieldiana: Anthropology 36: 81-146.

Vila, C., Savolainen, P., Maldonado, J.E., Amorim, I.R., Rice, J.E., Honeycutt, R.L., Crandall, K.A., Lundeberg, J. and Wayne, R.K. 1997. 'Multiple and ancient origins of the domestic dog', Science 276: 1687-9.

Wayne, R.K. and Ostrander, E. 1999. 'Origin, genetic diversity and genome structure of the domestic dog', Bio-Essays 21: 247-57.

White, Isobel M. 1972. 'Hunting dogs at Yalata', Mankind 8(3): 201-205.

Wing, E.S. 1977. 'Animal domestication in the Andes', in Reed, C.A. (ed.) Origins of agriculture. Mouton, Amsterdam. 